\title{
Analisis Faktor-Faktor Struktur Modal dan Nilai Perusahaan
}

\author{
Henny Wirianata dan Amin Wijoyo \\ Fakultas Ekonomi dan Bisnis, Universitas Tarumanagara
}

Email:

hennyw@fe.untar.ac.id

\begin{abstract}
Regression test results show only profitability affects the capital structure, while liquidity, growth, and size, do not affect. Profitability, size, and capital structure affect firm value, while liquidity and growth do not affect. Research on the capital structure and firm value was conducted in the manufacturing industry listed in IDX from 2016 to 2018. Data samples are taken using purposive random sampling and then processed with Eviews 10. Moderation test results indicate that the capital structure is a mediator of the effect of profitability on firm value, but cannot be a mediator for the influence of other variables on firm value of manufacturing industry companies listed in IDX 2016 through 2018.
\end{abstract}

Keywords: Profitability, liquidity, growth, size, capital structure, firm value

\begin{abstract}
Abstrak: Hasil uji regresi menunjukkan hanya profitabilitas yang mempengaruhi struktur modal, sementara likuiditas, pertumbuhan, dan ukuran, tidak mempengaruhi. Profitabilitas, ukuran, dan struktur modal mempengaruhi nilai perusahaan, sementara likuiditas dan pertumbuhan tidak mempengaruhi. Penelitian atas struktur modal dan nilai dari perusahaan dilakukan pada industri manufaktur terdaftar di BEI tahun 2016 sampai 2018. Sampel data diambil secara purposive random sampling kemudian diolah dengan Eviews 10. Hasil uji moderasi mengindikasikan bahwa struktur modal adalah mediator atas pengaruh profitabilitas terhadap nilai dari perusahaan, tetapi tidak dapat menjadi mediator atas pengaruh variabel bebas lainnya terhadap nilai perusahaan industri manufaktur terdaftar di BEI tahun 2016 sampai 2018.
\end{abstract}

Kata kunci: profitabilitas, likuiditas, pertumbuhan, ukuran, struktur modal, nilai perusahaan

\section{PENDAHULUAN}

Perusahaan pada umumnya bertujuan memberikan keuntungan bagi pemilik modal yang dapat diukur dari nilai perusahaan. Keuntungan bagi pemilik modal tercermin dari tingginya nilai pasar saham perusahaan. Nilai perusahaan yang tinggi akan mempengaruhi persepsi calon pemilik modal potensial yang berdampak pada rasa percaya mereka akan prospek perusahaan di masa depan (Purwohandoko, 2017).

Pengelolaan keuangan berkaitan langsung dengan keputusan pendanaan yang mempengaruhi struktur modal perusahaan. Bagus atau tidaknya struktur modal perusahaan akan mempengaruhi posisi dan kinerja keuangan perusahaan yang mempengaruhi nilai perusahaan (Darsono, 2017). Struktur modal menggambarkan sumber pendanaan untuk 
perusahaan melakukan kegiatan operasinalnya, yaitu pendanaan internal menggunakan modal yang bersumber dari pemegang saham dan pendanaan dari luar dalam bentuk hutang.

Penentuan struktur modal dan tinggi rendahnya nilai perusahaan dapat dipengaruhi oleh beberapa faktor. Seperti yang dikemukakan oleh (Brigham dan Houston, 2011:188), diantaranya penjualan yang stabil, struktur aktiva, operating leverage, pertumbuhan, profitabilitas, pajak atas pendapatan, sikap pemberi pinjaman, tindakan dan sikap manajemen, penilaian pemberi peringkat, keadaan pasar, internal perusahaan, dan kondisi keuangan yang fleksibel.

Pecking order theory menyatakan kebanyakan perusahaan akan lebih memilih pendanaan dari internal daripada dari eksternal. Profit perusahaan yang tinggi mengindikasikan peningkatan pada cadangan laba yang ditahan dan peningkatan modal perusahaan, sehingga mendorong peningkatan nilai perusahaan dan semakin kecilnya proporsi hutang dalam perusahaan.

Perusahaan yang likuid merupakan sinyal positif bahwa investor percaya perusahaan dapat menyelesaikan seluruh kewajibannya saat jatuh tempo (Rahmansyah dan Djumahir, 2018). Hal ini dapat mendorong peningkatan nilai dari perusahaan. Perusahaan yang likuid akan berdampak menurunkan struktur modal karena kecilnya pendanaan eksternal dibandingkan pendanaan internal. Para pemegang saham memiliki rasa aman karena semakin likuid perusahaan maka tingkat risiko investasi akan berkurang.

Perusahaan yang bertumbuh adalah perusahaan yang mampu berkembang setiap tahun/periode. Nilai perusahaan akan meningkat jika tingkat pertumbuhan perusahaan menunjukkan nilai yang tinggi. Namun, perusahaan yang mempunyai pertumbuhan perusahaan yang tinggi lebih memilih pendanaan dari eksternal dibandingkan pendanaan dari internal. Perusahaan yang menunjukkan tingkat pertumbuhan yang baik dapat memberikan pengaruh negatif bagi struktur modal perusahaan, tetapi memberikan pengaruh positif untuk nilai perusahaan.

Perusahaan besar memiliki tingkat risiko usaha yang lebih rendah karena dianggap dapat menjamin pengembalian investasi yang tinggi sehingga menambah rasa percaya investor pada perusahaan. Perusahaan besar mengindikasikan perusahaan memiliki kemampuan pengendalian yang lebih baik dan lebih stabil di pasar serta mampu menghadapi persaingan. Hal ini berdampak positif pada nilai perusahaan. Perusahaan yang besar juga dianggap memiliki kemampuan yang lebih fleksibel dalam memperoleh pendanaan eksternal (Susanti dan Restiana, 2018) sehingga dapat mendorong peningkatan struktur modal.

Penelitian ini menganalisis sampel perusahaan terdaftar di Bursa Efek Indonesia untuk industri manufaktur tahun 2016 sampai 2018. Tahun 2018, industri manufaktur Indonesia menjadi industri yang memberikan peranan pada makro ekonomi Indonesia yaitu memberikan kontribusi 22\% terhadap Produk Domestik Bruto (PDB) Indonesia. (https://industri.kontan.co.id/news).

\section{KAJIAN TEORI}

Trade-off Theory. Perusahaan dengan struktur modal dari pendanaan eksternal yang tinggi akan menimbulkan pembayaran bunga yang besar bagi perusahaan. Pembayaran bunga yang tinggi akan menurunkan pendapatan sebelum pajak yang berarti akan menurunkan pajak yang akan dibayar perusahaan. Dengan demikian, peningkatan penggunaan dana 
eksternal dapat meningkatkan nilai perusahaan yang disebabkan oleh adanya beban bunga yang akan menurunkan beban pajak bagi perusahaan.

Perusahaan tanpa pendanaan eksternal tidak memiliki beban bunga dan memiliki kewajiban membayar pajak yang lebih tinggi dari perusahaan yang memiliki pendanaan eksternal dalam struktur modalnya, dan kondisi ini akan berdampak pada penurunan nilai perusahaan (Zuhroh, 2019). Perusahaan dengan sumber dana eksternal memiliki risiko kebangkrutan namun risiko itu dapat digantikan dari manfaat pajak karena adanya beban bunga. Kondisi inilah yang merupakan konsep dalam trade-off theory.

Dalam trade-off theory juga dijelaskan apabila struktur modal dari perusahaan ada pada posisi optimal, maka nilai dari perusahaan akan meningkat seiring meningkatnya struktur modal. Sementara, jika struktur modal perusahaan melebihi titik optimal, maka kenaikan pada pendanaan eksternal akan mengakibatkan turunnya nilai perusahaan. Oleh sebab itu, keputusan sumber pendanaan perusahaan yang mengoptimalkan struktur modal akan mempengaruhi nilai perusahaan (Purwohandoko, 2017).

Pecking Order Theory. Teori ini mengungkapkan perusahaan cenderung memilih pendanaan dengan risiko rendah, seperti risiko berkurangnya harga saham dan nilai dari perusahaan. Teori pecking order juga menggambarkan cara perusahaan memilih sumber pendanaan berdasarkan urutan risiko, yaitu dari yang paling tidak berisiko sampai dengan risiko paling tinggi dengan urutan pendanaan internal menggunakan laba ditahan, pendanaan eksternal menggunakan hutang, dan pendanaan eksternal menggunakan modal saham (Wahyu dan Mahfud, 2018).

Dengan mengoptimalkan struktur modal perusahaan, akan menyeimbangkan risiko perusahaan dengan nilai perusahaan. Sebuah perusahaan yang memiliki pendanaan eksternal yang kecil memiliki risiko usaha yang kecil sehingga meningkatkan nilai saham dan nilai perusahaan. Sebaliknya, pendanaan eksternal yang terlalu besar akan meningkatkan risiko usaha dan menurunkan nilai saham dan nilai perusahaan.

Teori Sinyal (Signaling Theory). Menurut (Tasir et al., 2017), teori sinyal fokus kepada pentingnya pemberian informasi dari perusahaan yang akan mempengaruhi pengambilan keputusan oleh para calon investor. Manajemen terkadang memiliki gambaran kondisi perusahaan yang lebih akurat daripada pihak eksternal perusahaan, yang dikenal sebagai assymetric information. Perbedaan jumlah informasi yang diterima para calon investor ini akan memberikan pengaruh yang penting pada pendanaan struktur modal perusahaan.

Perusahaan dengan prospek yang menguntungkan cenderung memilih pendanaan eksternal dan menghindari penerbitan saham, sehingga berdampak pada tingginya pendanaan eksternal. Sebaliknya, perusahaan prospek yang kurang menguntungkan akan menerbitkan saham baru supaya dapat membagi kerugian yang mungkin terjadi dengan investor baru (Jusrizal dan Aloysius, 2017). Oleh karena itu, pendanaan internal dengan menerbitkan saham baru akan menjadi sinyal negatif bagi investor karena dapat mengindikasikan perusahaan memiliki prospek keuangan yang kurang menguntungkan. Hal ini menyebabkan turunnya nilai saham perusahaan dan dapat mengakibatkan penurunan pada nilai perusahaan.

Namun, apabila perusahaan sudah dalam kondisi maju tetapi memiliki pendanaan eksternal yang lebih besar dari modal sendiri akan mendorong perusahaan untuk menerbitkan saham dengan tujuan uang hasil penerbitan saham digunakan untuk melunasi 
hutang. Kondisi ini akan mengurangi beban bunga perusahaan dan mendorong peningkatan nilai perusahaan.

Pengaruh Profitabilitas pada Struktur Modal. Secara umum, profitabilitas menggambarkan kinerja perusahaan dalam memperoleh laba dan menggambarkan kinerja operasional perusahaan dalam satu periode tertentu. Pecking order theory mengutamakan pendanaan internal dalam bentuk saldo laba ditahan. Perusahaan yang mampu mendanai kegiatan operasionalnya sendiri dari pendanaan internal berarti memiliki tingkat profitabilitas yang tinggi. Sejalan dengan pecking order theory pendanaan internal akan lebih diutamakan dibandingkan pendanaan eksternal. Oleh sebab itu, profitabilitas yang tinggi dapat mempengaruhi struktur modal secara negatif.

Pengaruh Likuiditas pada Struktur Modal. Likuiditas menunjukkan kesanggupan dari perusahaan melunasi hutangnya yang telah jatuh tempo. Perusahaan dengan tingkat likuiditas yang besar mengindikasikan rendahnya tingkat hutang perusahaan. Semakin likuid perusahaan dapat mengakibatkan turunnya struktur modal karena pendanaan internal lebih besar dibandingkan pendanaan eksternal. Menurut pecking order theory, jika kondisi likuiditas perusahaan tinggi berarti perusahaan tidak menggunakan pendanaan dengan hutang. Semakin tinggi tingkat likuiditas berarti tingkat struktur modal dari perusahaan menjadi berkurang.

Pengaruh Pertumbuhan pada Struktur Modal. Pertumbuhan menjadi salah satu tolok ukur dalam menilai kesuksesan perusahaan. Pertumbuhan perusahaan dapat dilihat dari pertambahan aset, pertambahan penjualan, ataupun dari pertumbuhan pangsa pasar perusahaan. Pertumbuhan perusahaan yang tinggi menggambarkan perusahaan dalam kondisi yang sehat sehingga memiliki kesempatan memperoleh pendanaan eksternal dan berdampak menaikkan struktur modal.

Pengaruh Ukuran pada Struktur Modal. Besarnya total aset yang dikelola dalam kegiatan operasional perusahaan dapat menggambarkan ukuran sebuah perusahaan. Manajemen perusahaan akan lebih fleksibel dan lebih mudah mengelola asset yang dimiliki jika total asset perusahaan besar. Perusahaan dengan risiko usaha yang kecil juga dapat dilihat oleh investor dari besarnya aset yang dimiliki perusahaan. Dengan tingkat risiko usaha yang kecil maka perusahaan dianggap memiliki kemampuan untuk mengembalikan hasil investasi dari penggunaan asetnya. Total aset yang besar juga dapat memberikan peluang yang lebih mudah untuk mendapatkan pendaaan eksternal melalui pasar modal (Rahmansyah dan Djumahir, 2018). Kondisi ini berdampak pada peningkatan struktur modal.

Pengaruh Profitabilitas pada Nilai Perusahaan. Tingginya profitabilitas mengindikasikan semakin efektif serta semakin efisien operasional perusahaan. Laba yang tinggi akan berdampak pada peningkatan earning per share yang berarti meningkatkan kesejahteraan pemilik modal. Dengan demikian, perusahaan dengan profitabilitas tinggi dapat mendorong peningkatan nilai perusahaan. 
Pengaruh Likuiditas pada Nilai Perusahaan. Perusahaan yang likuid berarti mampu menunjukkan kesanggupannya melunasi hutang lancar yang akan jatuh tempo. Hal ini merupakan pertanda baik bagi pemegang saham dan memberikan rasa percaya kepada kreditor. Penelitian yang dilakukan (Jacob dan Taslim, 2017) menyebutkan bahwa nilai perusahaan dipengaruhi signifikan oleh CR. Semakin besar nilai CR berarti menunjukkan semakin tinggi peluang perusahaan melunasi hutang lancarnya sehingga akan mendorong kenaikan pada nilai perusahaan (Jacob dan Taslim, 2017).

Pengaruh Pertumbuhan pada Nilai Perusahaan. Perusahaan yang mengalami pertumbuhan aset mengindikasikan perusahaan menggunakan pendanaan yang dimilikinya secara efektif dan efisien. Dengan tingkat pertumbuhan asset tinggi, maka investor memiliki persepsi baik sehingga mendorong peningkatan nilai dari perusahaan.

Pengaruh Ukuran pada Nilai Perusahaan. Besar kecilnya perusahaan merupakan informasi bagi investor dan kreditur karena mempengaruhi tingkat risiko investasi. Investor memiliki persepsi dengan ukuran perusahaan yang besar maka akan memudahkan perusahaan dalam memperoleh sumber dana yang mempengaruhi nilai perusahaan (Purwanto dan Agustin, 2017). Besarnya ukuran perusahaan juga berhubungan erat dengan pengambilan keputusan pendanaan perusahaan dalam mengoptimalkan nilai perusahaan (Suwardika dan Mustanda, 2017).

Struktur Modal dan Pengaruhnya Terhadap Nilai Perusahaan. Besarnya pendanaan eksternal dari pendanaan internal menggambarkan tingginya struktur modal. Adanya beban bunga yang berasal dari pendanaan eksternal berdampak pada turunnya pajak, sehingga laba setelah dipotong pajak meningkat dan laba untuk setiap lembar saham juga meningkat. Kondisi ini sejalan dengan trade-off theory dimana manfaat pajak akan menggantikan pendanaan dari hutang.

Pendanaan dari hutang juga berarti perusahaan tidak perlu menerbitkan saham baru, dimana lembar saham beredar akan bertambah dan menurunkan besarnya pengembalian untuk pemegang saham. Peningkatan struktur modal akan memberi rasa aman kepada investor karena menunjukkan perusahaan yakin akan kemampuannya melunasi hutang dan (Indasari dan Yadnaya, 2018). Dengan demikian, meningkatnya struktur modal dapat berdampak positif pada harga pasar dan nilai perusahaan.

Kerangka Pemikiran dan Hipotesis. Gambar 1 menjelaskan kerangka pemikiran. 


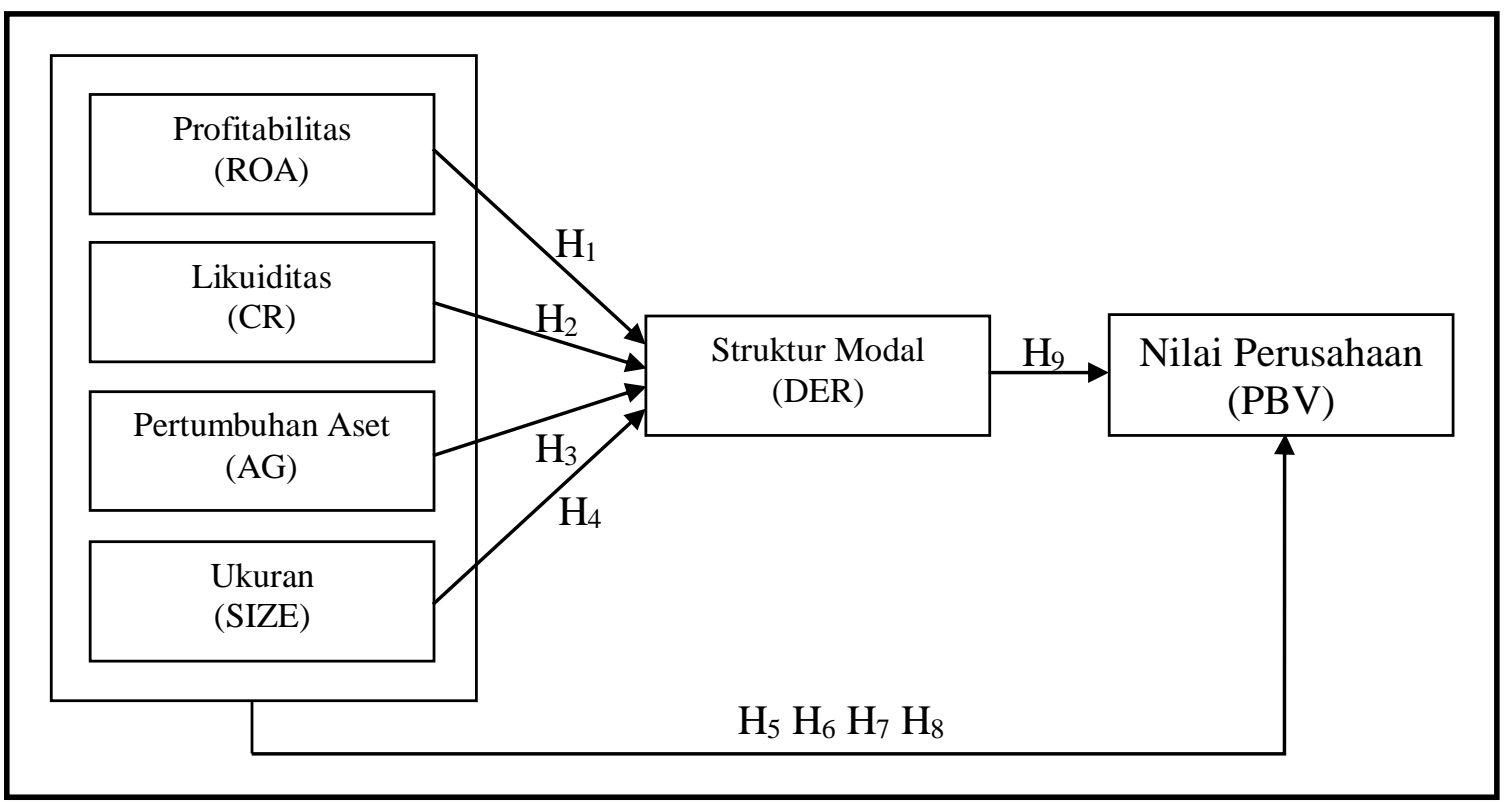

Gambar 1. Kerangka Pemikiran

Pengembangan hipotesis diuraikan berikut ini:

$\mathrm{H}_{1} \quad$ : Profitabilitas secara signifikan menurunkan struktur modal

$\mathrm{H}_{2} \quad$ : Likuiditas secara signifikan menurunkan struktur modal

$\mathrm{H}_{3}$ : Pertumbuhan perusahaan secara signifikan meningkatkan struktur modal

$\mathrm{H}_{4}$ : Ukuran perusahaan secara signifikan meningkatkan struktur modal

$\mathrm{H}_{5}$ : Profitabilitas secara signifikan meningkatkan nilai perusahaan

$\mathrm{H}_{6}$ : Likuiditas secara signifikan meningkatkan nilai perusahaan

$\mathrm{H}_{7}$ : Pertumbuhan perusahaan secara signifikan meningkatkan nilai perusahaan

$\mathrm{H}_{8} \quad$ : Ukuran perusahaan secara signifikan meningkatkan nilai perusahaan

$\mathrm{H}_{9}$ : Struktur modal secara signifikan meningkatkan nilai perusahaan

\section{METODELOGI}

Populasi dan Teknik Pemilihan Sampel. Sampel data diambil dari populasi industri manufaktur di BEI selama periode 2016 sampai 2018. Kriteria pemilihan sampel dengan purposive sampling sebagai berikut: perusahaan manufaktur yang secara terus menerus terdaftar di BEI; tidak melakukan penawaran saham perdana dan tidak delisting selama periode penelitian, serta memiliki variabel penelitian yang lengkap.

Identifikasi dan Pengukuran Variabel. Variabel bebas yang dianalisis adalah probabilitas dengan Return on Assets (ROA), likuiditas dengan Current Ratio (CR), pertumbuhan dengan menggunakan Pertumbuhan Aset/Asset Growth (AG), dan ukuran/Size (SIZE). Variabel terikat dalam penelitian ini terdiri dari Price to Book Value (PBV) sebagai proksi dari nilai perusahaan dan Debt to Equity Ratio (DER) untuk proksi struktur modal, dimana struktur modal juga menjadi variabel mediasi. 
Teknik Pengumpulan Data. Data penelitian adalah data sekunder berupa rasio-rasio dari laporan keuangan sampel perusahaan yang telah memenuhi kriteria. Semua data yang digunakan diakses dari situs web perusahaan, situs web BEI, dan situs web sahamok. Data diolah menggunakan program E-views 10. Persamaan regresi untuk penelitian sebagai berikut:

$$
\begin{array}{r}
\mathrm{DER}_{\text {it }}=\alpha+\beta_{1} \mathrm{ROA}_{\text {it }}+\beta_{2} \mathrm{CR}_{\mathrm{it}}+\beta_{3} \mathrm{AG}_{\mathrm{it}}+\beta_{4} \mathrm{SIZE}_{\mathrm{it}}+\varepsilon_{\mathrm{it}} \\
\mathrm{PBV}_{\mathrm{it}}=\alpha+\beta_{1} \mathrm{ROA}_{\mathrm{it}}+\beta_{2} \mathrm{CR}_{\mathrm{it}}+\beta_{3} \mathrm{AG}_{\mathrm{it}}+\beta_{4} \mathrm{SIZE}_{\mathrm{it}}+\varepsilon_{\mathrm{it}} \\
\mathrm{PBV}_{\mathrm{it}}=\alpha+\beta_{1} \mathrm{DER}_{\mathrm{it}}+\varepsilon_{\mathrm{it}} \ldots \ldots \ldots \ldots \ldots \ldots
\end{array}
$$

\begin{tabular}{|c|c|}
\hline PBV & $=$ Price to Book Value Ratio \\
\hline DER & $=$ Debt to Equity Ratio \\
\hline ROA & $=$ Return on Assets \\
\hline $\mathrm{CR}$ & $=$ Current Ratio \\
\hline $\mathrm{AG}$ & $=$ Pertumbuhan Aset \\
\hline SIZE & $=$ Ukuran Perusahaan \\
\hline$\alpha$ & $=$ Konstanta \\
\hline$\beta_{1}-\beta_{9}$ & $=$ Koefisien Regresi \\
\hline$\varepsilon$ & $=$ Error \\
\hline
\end{tabular}

Keterangan:

\section{HASIL DAN PEMBAHASAN}

Analisis Statistik Deskriptif. Analisis pendahuluan adalah analisis deskriptif untuk menggambarkan karakteristik data dari penelitian ini. Data untuk analisis deskriptif adalah

\begin{tabular}{|c|c|c|c|c|c|c|}
\hline & PBV & DER & ROA & CR & GROWTH & SIZE \\
\hline Mean & 4.828568 & 0.806279 & 0.096580 & 11.51095 & 0.135714 & 28.78572 \\
\hline Median & 1.932954 & 0.583373 & 0.072609 & 2.396391 & 0.094864 & 28.50543 \\
\hline Maximum & 82.44443 & 2.654552 & 0.526704 & 286.8300 & 0.802731 & 33.44014 \\
\hline Minimum & 0.207963 & 0.083299 & 0.001377 & 0.605600 & 0.002206 & 26.31928 \\
\hline Std. Dev. & 10.66230 & 0.636050 & 0.091404 & 41.08939 & 0.141164 & 1.479404 \\
\hline
\end{tabular}
sebanyak 132 data pengamatan dari periode 2016-2018 dengan hasil di bawah ini:

Tabel 1. Statistik Deskriptif

Variabel DER, ROA, dan SIZE memiliki nilai untuk standar deviasi lebih rendah dari nilai rata-ratanya, yang berarti rendahnya variasi DER, ROA, dan SIZE perusahaan sampel. Standar deviasi PBV, CR, dan GROWTH lebih tinggi dari nilai rata-ratanya yang berarti PBV, CR, dan GROWTH perusahaan sampel memiliki variasi yang tinggi.

Nilai rata-rata DER sebesar 0,806279 berarti perusahaan sampel memiliki rata-rata tingkat hutang $80,63 \%$ dari total ekuitas yang dimiliki. ROA memiliki nilai rata-rata sebesar 0,096580 menunjukkan masih rendahnya kemampuan menghasilkan laba perusahaan 
sampel yaitu sebesar 9,66\% dari total aset perusahaan. CR perusahaan sampel memiliki nilai rata-rata 11,51095 yang berarti perusahaan sampel memiliki tingkat likuiditas yang tinggi dimana untuk setiap 1 rupiah hutang lancar perusahaan sampel yang dilunasi masih tersisa 10,51095 aset lancar yang dapat digunakan untuk kegiatan operasional, investasi dan pendanaan.

Pertumbuhan (GROWTH) dari perusahaan sampel memiliki nilai rata-rata 0,135714 $(13,57 \%)$ yang mengindikasikan masih rendahnya tingkat pertumbuhan perusahaan sampel jika dibandingkan dengan nilai maksimum pertumbuhan perusahaan sampel yaitu 0,802731 $(80,27 \%)$. Nilai rata-rata ukuran perusahaan juga lebih rendah $(28,78572)$ jika dibandingkan nilai maksimum ukuran perusahaan sampel yaitu 33,44014.

Hasil Uji Multikolinearitas. Berdasarkan hasil uji multikolinearitas, nilai koefisien kolerasi seluruh variabel bebas lebih kecil dari 0,8 sehingga tidak terjadi multikolinearitas (lihat Tabel 2).

Tabel 2. Hasil Multikolinearitas

\begin{tabular}{cccrrr}
\hline \hline & DER & ROA & CR & GROWTH & \multicolumn{1}{c}{ SIZE } \\
\hline \hline DER & 1.000000 & 0.054916 & -0.130763 & 0.064210 & 0.160628 \\
ROA & 0.054916 & 1.000000 & -0.099458 & -0.083352 & 0.183202 \\
CR & -0.130763 & -0.099458 & 1.000000 & 0.003866 & -0.018610 \\
GROWTH & 0.064210 & -0.083352 & 0.003866 & 1.000000 & -0.102427 \\
SIZE & 0.160628 & 0.183202 & -0.018610 & -0.102427 & 1.000000 \\
\hline \hline
\end{tabular}

Sumber: Data diolah (2020)

Pemilihan Model Estimasi. Penelitian ini memiliki tiga model penelitian. Pengujian yang dilakukan dalam memilih model estimasi untuk model penelitian $1\left(\mathrm{H}_{1}-\mathrm{H}_{4}\right)$, model penelitian $2\left(\mathrm{H}_{5}-\mathrm{H}_{8}\right)$ dan model penelitian $3\left(\mathrm{H}_{9}\right)$ diuraikan pada Tabel 3.

Tabel 3. Hasil Uji Model Estimasi

\begin{tabular}{l|c|c|c|c|c|c}
\hline \multirow{2}{*}{ Pengujian } & \multicolumn{2}{|c|}{ Model 1 $\left(\mathbf{H}_{1}-\mathbf{H}_{4}\right)$} & \multicolumn{2}{c|}{ Model 2 $\left(\mathbf{H}_{5}-\mathbf{H}_{8}\right)$} & \multicolumn{2}{c}{ Model 3 (H9) } \\
\cline { 2 - 7 } & Prob. & Kesimpulan & Prob. & Kesimpulan & Prob. & Kesimpulan \\
\hline $\begin{array}{l}\text { Uji Chow } \\
\text { Cross-section Chi-square }\end{array}$ & 0,0000 & FEM & 0,0000 & FEM & 0,0000 & FEM \\
\hline $\begin{array}{l}\text { Uji Hausman } \\
\text { Cross-section Random }\end{array}$ & 0,1569 & REM & 0,0000 & FEM & 0,8544 & REM \\
\hline $\begin{array}{l}\text { Uji Langrange Multiplier } \\
\text { Breush-Pagan }(P \text { value) }\end{array}$ & 0,0000 & REM & - & - & 0,0000 & REM \\
\hline
\end{tabular}

FEM = Fixed Effect Model, REM = Random Effect Model

Sumber: Data diolah (2020)

Hasil uji Chow untuk model penelitian 1, 2, dan 3 pada Tabel 3 menunjukkan nilai probabilitas untuk ketiga model penelitian adalah dibawah 0,05 berarti yang lebih baik adalah model fixed effect. Model penelitian 1 dan 3 memiliki hasil uji Hausman dengan probabilitas diatas 0,05 yang menunjukkan bahwa model random effect lebih baik. Untuk menguatkan hasil tersebut dilakukan uji Langrange Multiplier. Hasil Uji Langrange 
Multiplier menunjukkan hasil probabilitas Breusch-Pagan (P value) dibawah 0,05. Model estimasi terbaik untuk model penelitian $1\left(\mathrm{H}_{1}-\mathrm{H}_{4}\right)$ dan model penelitian $3\left(\mathrm{H}_{9}\right)$ adalah random effect. Sementara, model penelitian 2 memiliki hasil uji Hausman dengan probabilitas dibawah 0,05. Dengan demikian model fixed effect lebih baik, maka model penelitian $2\left(\mathrm{H}_{5}-\mathrm{H}_{8}\right)$ menggunakan model fixed effect.

Hasil Uji Regresi Model Penelitian 1. Tabel 4 menunjukkan hasil uji regresi berganda untuk model penelitian 1 yang dapat dirumuskan dengan:

$$
\begin{aligned}
\text { DER }=-1,526844 & -1,837117 \text { ROA }-0,001589 \mathrm{CR}-0,245679 \text { AG } \\
& +0,086692 \text { SIZE }+ \text { e } \ldots \ldots \ldots \ldots \ldots \ldots \ldots \ldots \ldots \ldots \ldots \ldots \ldots \ldots \ldots \ldots \ldots
\end{aligned}
$$

Keterangan :

$\begin{array}{ll}\text { DER } & =\text { Debt to Equity Ratio } \\ \text { ROA } & =\text { Return on Assets } \\ \text { CR } & =\text { Current Ratio } \\ \text { AG } & =\text { Pertumbuhan Aset } \\ \text { SIZE } & =\text { Ukuran Perusahaan } \\ \varepsilon & =\text { Error }\end{array}$

Tabel 4. Uji Regresi Model Penelitian 1

\begin{tabular}{crrrr}
\hline \hline \multicolumn{1}{c}{ Variable } & Coefficient & Std. Error & t-Statistic & Prob. \\
\hline \hline C & -1.526844 & 1.728384 & -0.883394 & 0.3787 \\
ROA & -1.837117 & 0.536613 & -3.423544 & 0.0008 \\
CR & -0.001589 & 0.001609 & -0.987809 & 0.3251 \\
GROWTH & 0.245679 & 0.153043 & 1.605290 & 0.1109 \\
SIZE & 0.086692 & 0.059714 & 1.451784 & 0.1490 \\
\hline \hline R-squared & 0.117302 & & & \\
Adjusted R-squared & 0.089500 & & & \\
Prob(F-statistic) & 0.003061 & & & \\
\hline \hline
\end{tabular}

Sumber: Data diolah (2020)

Nilai konstanta pada persamaan regresi untuk model penelitian 1 menunjukkan nilai 1,526844, yang berarti nilai DER akan turun 1,526844 satuan apabila semua variabel independen bernilai nol atau tetap. Koefisien regresi untuk ROA $-1,837117$, yang berarti jika ROA mengalami kenaikan 1 satuan akibatnya DER akan mengalami penurunan 1,837117 satuan dan variabel lainnya bernilai tetap atau nol. DER juga akan mengalami penurunan 0,001589 satuan apabila CR mengalami kenaikan 1 satuan dengan variabel lainnya bernilai tetap atau nol.

Pertumbuhan aset memiliki koefisien regresi 0,245679, maka nilai DER akan naik 0,245679 satuan apabila pertumbuhan perusahaan naik 1 satuan dengan variabel lainnya nol. Nilai koefisien regresi ukuran perusahaan 0,086692, maka nilai DER akan naik 0,086692 satuan apabila ukuran perusahaan mengalami kenaikan 1 satuan dengan variabel independen lainnya bernilai tetap atau nol.

Uji F untuk model penelitian pertama pada Tabel 4 menunjukkan nilai F Statistic 0,003061 yang berarti model regresi pertama memenuhi the goodness of fit, yang juga 
berarti bahwa struktur modal dipengaruhi signifikan oleh semua variabel bebas secara bersama-sama.

Hasil Uji t dari tabel 4 untuk $\mathrm{H}_{1}-\mathrm{H}_{4}$ diuraikan berikut ini: (1) Profitabilitas memiliki nilai koefisien regresi -1,837117 dengan probabilitas 0,0008 , yang berarti $\mathrm{H}_{1}$ dapat diterima yaitu ROA memberikan pengaruh signifikan yang akan menurunkan nilai Struktur Modal (DER). (2) Koefisien regresi untuk Likuiditas -0,001589 dan probabilitas 0,3251, sehingga $\mathrm{H}_{2}$ tidak dapat diterima. CR dalam penelitian ini dapat menurunkan tingkat Struktur Modal (DER) tapi pengaruh tersebut tidak signifikan. (3) Pertumbuhan perusahaan mempunyai koefisien regresi 0,245679 dan probabilitas $0,1109 . \mathrm{H}_{3}$ tidak dapat diterima, yang mengindikasikan kenaikan pertumbuhan perusahaan (Asset Growth) dapat menambah tingkat Struktur Modal (DER) tetapi tidak secara signifikan. (4) Ukuran perusahaan dengan nilai koefisien regresi sebesar 0,086692 dan probabilitas $0,1490 . \mathrm{H}_{4}$ ditolak karena semakin besar ukuran suatu perusahaan (Firm Size) tidak secara signifikan dapat meningkatkan Struktur Modal (DER).

Dari Tabel 4, hasil uji koefiesien determinasi menunjukkan adjusted $R^{2}$ 0,089500. Nilai ini berarti sebesar 8,95\% tingkat Struktur Modal perusahaan dijelaskan oleh adanya variabel Profitabilitas, Likuiditas, pertumbuhan perusahaan, dan ukuran perusahaan, sementara $91,05 \%$ dijelaskan/dipengaruhi variabel lainnya di luar dari penelitian ini.

Hasil Uji Regresi Model Penelitian 2. Uji regresi berganda untuk model penelitian 2 tersaji pada Tabel 5 .

Tabel 5. Uji Regresi Model Penelitian 2

\begin{tabular}{crrrr}
\hline \hline Variable & Coefficient & Std. Error & t-Statistic & Prob. \\
\hline \hline C & 214.8369 & 77.03622 & 2.788777 & 0.0065 \\
ROA & -45.76157 & 10.70719 & -4.273910 & 0.0001 \\
CR & -0.020629 & 0.032355 & -0.637584 & 0.5255 \\
GROWTH & 1.955985 & 2.275667 & 0.859522 & 0.3925 \\
SIZE & -7.143010 & 2.656206 & -2.689177 & 0.0086 \\
\hline \hline R-squared & 0.955202 & & & \\
Adjusted R-squared & 0.930137 & & & \\
Prob(F-statistic) & 0.000000 & & & \\
\hline \hline
\end{tabular}

Sumber: Data diolah (2020)

Persamaan untuk model penelitian 2 dirumuskan sebagai berikut :

$$
\begin{array}{r}
\mathrm{PBV}=214,8369-45,76157 \mathrm{ROA}-0,020629 \mathrm{CR}+1,955985 \mathrm{AG} \\
-7,143010 \mathrm{SIZE}+\mathrm{e} \ldots \ldots \ldots \ldots \ldots \ldots \ldots \ldots
\end{array}
$$

Keterangan:

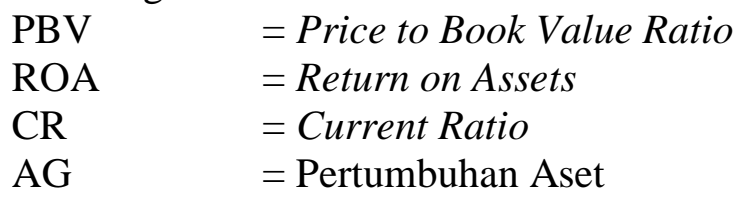


$\begin{array}{ll}\mathrm{SIZE} & =\text { Ukuran Perusahaan } \\ \varepsilon & =\text { Error }\end{array}$

Berdasarkan hasil persamaan regresi untuk model penelitian 2, didapatkan nilai konstanta 214,8369, yang berarti nilai PBV akan naik 214,8369 satuan apabila semua variabel bebas bernilai tetap atau nol. Koefisien regresi untuk ROA -45,76157, yang berarti nilai PBV akan turun 45,76157 satuan apabila ROA naik 1 satuan dan semua variabel independen lainnya bernilai tetap atau nol.

CR dan ukuran perusahaan juga memiliki nilai koefisien regresi negatif. Apabila CR naik 1 satuan dengan variabel lainnya bernilai tetap atau nol, nilai PBV turun 0,020629 satuan. Nilai PBV akan turun 7,143010 satuan jika ukuran perusahaan meningkat 1 satuan sementara variabel lainnya bernilai tetap atau nol. Sebaliknya, nilai PBV akan naik 1,955985 satuan apabila pertumbuhan perusahaan naik 1 satuan dan variabel ROA, CR dan ukuran perusahaan bernilai nol atau tetap.

Nilai probabilitas F Statistic dari hasil uji F untuk model penelitian 2 (lihat Tabel 5) adalah sebesar 0,000000, yang berarti model penelitian 2 ini memenuhi the goodness of fit. Secara kolektif semua variabel bebas memiliki pengaruh signifikan pada Nilai Perusahaan.

Hasil uji t dalam model penelitian 2 untuk $\mathrm{H}_{5}-\mathrm{H}_{8}$ : (1) Koefisien regresi Profitabilitas sebesar $-45,76157$ dan probabilitas $0,0001 . \mathrm{H}_{5}$ ditolak karena hasilnya menunjukkan Profitabilitas (ROA) memiliki pengaruh signifikan menurunkan Nilai Perusahaan (PBV). (2) Likuiditas dengan nilai koefisien regresi -0,020629 dan probabilitas 0,5255, maka $\mathrm{H}_{6}$ ditolak. Likuiditas (CR) memiliki pengaruh menurunkan Nilai Perusahaan (PBV) tetapi tidak secara signifikan. (3) Nilai koefisien regresi dari pertumbuhan perusahaan adalah 1,955985 dengan probabilitas 0,3925. $\mathrm{H}_{7}$ ditolak dimana Asset Growth dapat mendorong peningkatan Nilai Perusahaan (PBV) namun tidak signifikan. (4) Ukuran perusahaan memiliki probabilitas 0,0086 dengan nilai koefisien regresi -7,143010. Hasil ini berarti $\mathrm{H}_{8}$ tidak dapat diterima, dimana Firm Size secara signifikan dapat menurunkan Nilai Perusahaan (PBV).

Informasi pada Tabel 5 memperlihatkan nilai adjusted $R^{2}$ 0,930137. 93,01\% dari Nilai Perusahaan dipengaruhi oleh variabel Profitabilitas, variabel Likuiditas, variabel pertumbuhan perusahaan, dan variabel ukuran perusahaan. 6,99\% dari Nilai Perusahaan dijelaskan/dipengaruhi variabel lainnya diluar yang diujikan dalam penelitian ini.

Hasil Uji Regresi Model Penelitian 3. Hasil uji regresi untuk model penelitian 3 tersaji pada Tabel 6. Informasi pada Tabel 6 dapat dirumuskan dengan persamaan regresi untuk model penelitian 3 sebagai berikut:

$$
\mathrm{PBV}=-0,206615+6,244965 \mathrm{DER}+\mathrm{e}
$$

Keterangan:

$\begin{array}{ll}\text { PBV } & =\text { Price to Book Value Ratio } \\ \text { DER } & =\text { Debt to Equity Ratio } \\ \varepsilon & =\text { Error }\end{array}$


Tabel 6. Uji Regresi Model Penelitian 3

\begin{tabular}{lrrrr}
\hline \hline \multicolumn{1}{c}{ Variable } & Coefficient & Std. Error & t-Statistic & Prob. \\
\hline \hline C & -0.206615 & 1.763781 & -0.117143 & 0.9069 \\
DER & 6.244965 & 1.216040 & 5.135493 & 0.0000 \\
\hline \hline R-squared & 0.169705 & & & \\
Adjusted R-squared & 0.163318 & & & \\
Prob(F-statistic) & 0.000001 & & & \\
\hline \hline
\end{tabular}

Sumber: Data diolah (2020)

Nilai konstanta dari hasil persamaan regresi untuk model penelitian 3 bernilai negatif yang berarti apabila DER bernilai tetap atau nol, maka nilai PBV mengalami penurunan 0,206615 satuan. Nilai koefisien regresi untuk DER sebesar 6,244965 yang berarti nilai PBV akan naik 6,244965 satuan apabila DER naik 1 satuan.

Nilai probabilitas F Statistic dari hasil uji F untuk model penelitian 3 pada Tabel 6 adalah 0,000001, yang artinya model penelitian 3 memenuhi the goodness of fit.

Tabel 6 menunjukkan hasil uji t model penelitian 3 yaitu nilai koefisien regresi sebesar 6,244965 dan level signifikansi 0,0000. Dengan demikian $\mathrm{H}_{9}$ dapat diterima, yaitu Struktur Modal (DER) memiliki pengaruh signifikan meningkatkan Nilai Perusahaan (PBV).

Adjusted $R^{2}$ dari model penelitian 3 adalah 0.163318, sehingga dapat disimpulkankan bahwa Struktur Modal mampu menjelaskan/mempengaruhi Nilai Perusahaan sebesar 16,33\%. Sebesar 83,67\% dari Nilai Perusahaan dijelaskan/dipengaruhi oleh variabel lainnya.

\section{Hasil Uji Hipotesis dan pembahasan}

Pengaruh ROA, CR, Asset Growth, dan Firm Size pada Struktur Modal (DER). Hasil pengujian pada model penelitian 1 , menunjukan bahwa $\mathrm{H}_{1}$ dapat diterima dimana ROA memberi pengaruh signifikan menurunkan tingkat struktur modal (DER). Hasil ini sejalan dengan hasil penelitian (Tasir et al., 2017), (Prastika dan Candradewi, 2019), (Zuhroh, 2019), dan (Antoni et al., 2016) Dengan demikian, jika ROA naik maka DER akan turun. Perusahaan dengan tingkat profitabilitas tinggi cenderung memiliki Saldo Laba yang meningkat. Kondisi ini dapat mempengaruhi struktur modal karena pendanaan internal akan semakin lebih besar dibandingkan pendanaan eksternal.

Berbeda dengan (Salim dan Susilowati, 2019) dan (Darsono, 2017) yang menemukan struktur modal dipengaruhi secara negatif oleh profitabilitas (ROA) tetapi pengaruh tersebut tidak signifikan. Penelitian (Wardani, 2015) memberikan hasil sebaliknya, yaitu bahwa struktur modal tidak dipengaruhi oleh profitabilitas karena perusahaan melihat pada besarnya manfaat dan pengorbanan dari penggunaan hutang. Perusahaan juga tidak menjadikan besar atau kecilnya jumlah profit yang dihasilkan perusahaan untuk memutuskan komposisi struktur modalnya (Darsono, 2017).

CR memiliki pengaruh menurunkan struktur modal perusahaan (DER) tetapi tidak signifikan. $\mathrm{H}_{2}$ tidak diterima. Perusahaan dengan tingkat hutang yang rendah ditunjukkan dari tingginya tingkat likuiditas. Semakin likuid perusahaan, akan berpengaruh pada 
menurunnya pendanaan eksternal dalam komposisi struktur modal perusahaan. Meskipun hasil ini membuktikan bahwa tingginya likuiditas memberikan dampak menurunkan struktur modal, namun dampak tersebut tidak signifikan. Tingkat likuiditas belum menjadi faktor yang mempengaruhi komposisi struktur modal secara signifikan. Penelitian ini mendukung hasil penelitian (Darsono, 2017) tetapi tidak sejalan dengan (Antoni et al., 2016), (Tasir et al., 2017), (Zuhroh, 2019), (Salim dan Susilowati, 2019), dan (Prastika dan Candradewi, 2019) yang menemukan likuiditas dapat menurunkan struktur modal secara signifikan.

$\mathrm{H}_{3}$ ditolak yang berarti pertumbuhan aset tidak memberi pengaruh signifikan pada tingkat struktur modal. Pertumbuhan perusahaan bukan merupakan faktor yang secara signifikan berpengaruh pada tingkat struktur modal perusahaan. Hasil ini mendukung temuan (Dewi dan Sudiartha, 2017) dimana pertumbuhan aset tidak mempengaruhi struktur modal perusahaan. Sebaliknya, (Antoni et al., 2016), (Darsono, 2017), (Purwohandoko, 2017), dan (Tasir et al., 2017) menyatakan pertumbuhan aset memberikan dampak meningkatkan struktur modal. Sementara, (Salim dan Susilowati, 2019) menemukan pertumbuhan aset memberikan pengaruh negatif dan signifikan.

Hasil penelitian menunjukkan $\mathrm{H}_{4}$ tidak dapat diterima. Firm size tidak berpengaruh signifikan pada tingkat struktur modal. (Purwohandoko, 2017), (Salim dan Susilowati, 2019), serta (Dewi dan Sudiartha, 2017) menemukan hasil yang sama. Besarnya ukuran perusahaan tidak menjamin keberlanjutan perusahaan, oleh karena itu tidak menjamin ketertarikan investor dan kreditor untuk berinvestasi di perusahaan (Salim dan Susilowati, 2019).

Hasil yang bertolak belakang ditemukan oleh (Antoni et al., 2016), dan (Zuhroh, 2019), yang dalam penelitiannya menyatakan ukuran perusahaan secara signifikan dapat meningkatkan struktur modal perusahaan. Sementara, (Tasir et al., 2017) menemukan ukuran perusahaan memberikan pengaruh menurunkan tingkat struktur modal.

Pengaruh ROA, CR, Asset Growth, dan Firm Size pada Nilai Perusahaan (PBV). Hasil uji regresi dari model penelitian 2 menunjukkan bahwa $\mathrm{H}_{5}$ ditolak, dimana profitabilitas memberikan pengaruh negatif serta signifikan pada nilai perusahaan. (Yastini dan Mertha, 2015) dan (Wirianata, 2020) menemukan hasil yang sama. Profitabilitas yang tinggi mendorong peningkatan laba per saham namun tidak secara langsung akan memberikan kenaikan pada harga pasar dan nilai perusahaan (Wirianata, 2020).

Hasil ini belum sejalan dengan hasil penelitian (Salim dan Susilowati, 2019), (Purwanto dan Agustin, 2017), (Suwardika dan Mustanda, 2017), dan (Rahmansyah dan Djumahir, 2018) yang menemukan ROA memberikan pengaruh signifikan dalam meningkatkan nilai perusahaan. Tingginya tingkat profitabilitas mengindikasikan perusahaan mampu menghasilkan laba tinggi yang juga meningkatkan nilai perusahaan.

$\mathrm{H}_{6}$ dalam penelitian ini tidak dapat diterima. Hasil uji regresi menunjukkan likuiditas berpotensi menurunkan nilai perusahaan tetapi tidak signifikan. Hasil ini mendukung penelitian (Indasari dan Yadnaya, 2018). Likuiditas bukan merupakan faktor signifikan yang mempengaruhi kenaikan atau penurunan nilai dari perusahaan.

(Salim dan Susilowati, 2019), (Rahmansyah dan Djumahir, 2018), dan (Purwanto dan Agustin, 2017) mendapatkan hasil penelitian likuiditas memberi pengaruh signifikan pada nilai perusahaan tetapi pengaruh tersebut negatif. Perusahaan dengan tingkat likuiditas tinggi berarti menggunakan dana yang dimilikinya untuk melunasi hutang lancar dan 
menurunkan ketersediaan dana untuk pembayaran deviden kepada pemegang saham, sehingga likuiditas yang tinggi akan memberikan dampak negatif pada nilai perusahaan (Salim dan Susilowati, 2019).

Hasil uji regresi menunjukkan bahwa pertumbuhan aset memberikan pengaruh meningkatkan nilai perusahaan tetapi tidak berpengaruh signifikan, sehingga $\mathrm{H}_{7}$ ditolak. Dengan demikian, pertumbuhan aset bukan faktor yang mempunyai pengaruh pada pembentukan nilai perusahaan secara signifikan. Hasil ini mendukung (Rahmansyah dan Djumahir, 2018) yang dalam penelitiannya juga menemukan pertumbuhan aset tidak berpengaruh signifikan. Sementara, (Indasari dan Yadnaya, 2018) menemukan hasil berbeda yaitu pertumbuhan aset berpengaruh menaikkan nilai perusahaan. Kemudian (Salim dan Susilowati, 2019) menemukan bahwa pertumbuhan aset dapat menurunkan nilai perusahaan.

$\mathrm{H}_{8}$ dalam penelitian ini tidak dapat diterima, berarti semakin besar ukuran suatu perusahaan mengakibatkan nilai perusahaan mengalami penurunan. Perusahaan dengan jumlah aset yang besar belum tentu mampu mengelola pemakaian asetnya secara efisien untuk menambah nilai dari perusahaan. (Wirianata, 2020) juga menemukan bahwa ukuran perusahaan dapat menurunkan nilai perusahaan secara signifikan. Berbeda dengan (Purwanto dan Agustin, 2017) dan (Rahmansyah dan Djumahir, 2018), yang menemukan hasil penelitian nilai perusahaan dapat meningkat karena meningkatnya ukuran perusahaan. Sementara, (Suwardika dan Mustanda, 2017) dan (Salim dan Susilowati, 2019) menemukan nilai perusahaan tidak dipengaruhi besar kecilnya ukuran perusahaan. Hal ini dikarenakan para calon investor tidak selalu hanya melihat pada ukuran perusahaan tetapi melihat pula kinerja dan perspektif keuangan lainnya (Salim dan Susilowati, 2019).

Pengaruh DER terhadap Nilai Perusahaan (PBV). Hasil uji regresi model penelitian 3 mengindikasikan struktur modal berpengaruh signifikan meningkatkan nilai perusahaan, sehingga $\mathrm{H}_{9}$ dapat diterima. Struktur modal yang tinggi mengindikasikan perusahaan menggunakan pendanaan eksternal lebih besar dari pendanaan internal. Beban bunga yang timbul dari pendanaan eksternal akan berdampak pada turunnya beban pajak, sehingga laba setelah dipotong pajak meningkat dan laba untuk setiap lembar saham juga meningkat. Peningkatan pada struktur modal merupakan informasi positif bagi investor karena perusahaan yakin akan kemampuannya melunasi hutang dan memberi rasa aman kepada investor (Indasari dan Yadnaya, 2018). Dengan demikian, meningkatnya struktur modal dapat berdampak mendorong naiknya harga pasar dan naiknya nilai perusahaan.

(Wirianata, 2020), (Wahyu dan Mahfud, 2018), dan (Suwardika dan Mustanda, 2017), juga menemukan hasil penelitian yang sama. Namun, hasil berbeda ditemukan (Purwanto dan Agustin, 2017) dan (Rahmansyah dan Djumahir, 2018) yaitu struktur modal memberi pengaruh signifikan menurunkan nilai perusahaan. Tetapi (Salim dan Susilowati, 2019) dalam penelitiannya mendapatkan struktur modal tidak memberikan pengaruh signifikan pada peningkatan nilai perusahaan.

Hasil Uji Mediasi. Uji mediasi menggunakan Sobel Test dengan melihat nilai koefisien regresi dan standard error dari hasil persamaan regresi pada model penelitian 1 dan 3 . Nilai $\mathrm{z}$ dari pengujian Sobel Test disajikan pada Tabel 7.

Uji mediasi menggunakan Sobel Test menghasilkan nilai z untuk interaksi Profitabilitas (ROA) dengan Struktur Modal (DER) lebih besar dari 1.97 (2,8486 > 1,97) 
dengan tingkat probabilitas 0,0022 yang berarti bahwa Struktur Modal (DER) mampu menjadi mediator dalam hubungan Profitabilitas (ROA) dan Nilai Perusahaan (PBV) tetapi dengan arah negatif. Uji regresi pada struktur modal memperlihatkan bahwa ROA berpengaruh menurunkan tingkat struktur modal perusahaan (DER). Perusahaan dengan profitabilitas yang semakin meningkat cenderung memiliki cadangan laba yang ditahan yang semakin meningkat pula sehingga pendanaan internal akan semakin lebih besar dibandingkan pendanaan eksternal. Namun, hasil uji regresi mengindikasikan bahwa struktur modal akan meningkatkan nilai perusahaan, yang artinya apabila komposisi struktur modal dari perusahaan lebih banyak bersumber dari pendanaan eksternal akan mendorong peningkatan nilai dari perusahaan.

Tabel 7. Uji Mediasi (Sobel Test)

\begin{tabular}{l|c|c}
\hline \multicolumn{1}{c|}{ Interaksi } & Nilai z & Prob. \\
\hline Profitabilitas (ROA) x Struktur Modal (DER) & $-2,8486$ & 0,0022 \\
\hline Likuiditas (CR) x Struktur Modal (DER) & $-0,9698$ & 0,1661 \\
\hline Pertumbuhan Perusahaan (Asset Growth) x Struktur Modal (DER) & 1,5322 & 0,0627 \\
\hline Ukuran Perusahaan (Firm Size) x Struktur Modal (DER) & 1,3970 & 0,0812 \\
\hline
\end{tabular}

Sumber: Data diolah (2020)

Tingkat profitabilitas yang tinggi juga akan meningkatkan laba untuk setiap lembar saham tetapi tidak berarti otomatis akan menaikkan harga pasar dan nilai perusahaan (Wirianata, 2020). Profitabilitas yang tinggi akan mendorong turunnya pendanaan eksternal dalam komposisi struktur modal perusahaan. Menurunnya struktur modal yang berasal dari pendanaan eksternal akan menurunkan beban bunga yang harus dibayarkan perusahaan sehingga akan berdampak pada naiknya beban pajak, sehingga laba setelah dipotong pajak dan laba untuk setiap lembar saham menurun, yang akan berdampak pada menurunnya nilai pasar saham perusahaan dan menurunkan nilai perusahaan. Sebaliknya, profitabilitas yang rendah akan mendorong pendanaan eksternal meningkat, sehingga beban bunga meningkat, dan akibatnya beban pajak menurun, tetapi laba setelah pajak dan laba per saham meningkat. Dengan demikian, keputusan pendanaan atas komposisi struktur modal perusahaan merupakan mediator atas pengaruh profitabilitas pada nilai perusahaan namun dengan arah yang negatif. Kondisi ini juga terlihat dari hasil uji regresi atas pengaruh profitabilitas pada nilai perusahaan tanpa interaksi struktur modal yaitu memberikan pengaruh yang bersifat negatif.

Nilai z untuk interaksi Likuiditas (CR) dengan Struktur Modal (DER) lebih kecil dari $1.97(0,9698<1,97)$ dengan tingkat probabilitas 0,1661, maka Struktur Modal (DER) belum mampu menjadi mediator dalam hubungan antara CR dengan PBV. Hasil uji regresi menunjukkan Likuiditas berpengaruh menurunkan struktur modal namun tidak signifikan. Tingkat likuiditas yang tinggi mencerminkan rendahnya tingkat hutang, sehingga semakin likuid perusahaan seharusnya berdampak pada menurunnya pendanaan eksternal daripada pendanaan internal. Akan tetapi, karena perusahaan memiliki tingkat likuiditas tinggi, maka perusahaan akan memanfaatkan dana yang dimilikinya untuk melunasi hutang lancar, kondisi ini akan menurunkan ketersediaan dana untuk pembayaran deviden kepada pemegang saham. Menurunnya dana untuk pembagian dividen akan menjadi sinyal negatif bagi investor sehingga tingkat likuiditas yang tinggi dapat berdampak pada menurunnya 
nilai perusahaan (Salim dan Susilowati, 2019). Tanpa interaksi dengan struktur modal, hasil uji regresi mengindikasikan bahwa likuiditas memberikan pengaruh menurunkan nilai perusahaan tetapi tidak signifikan. Dengan demikian, struktur modal bukan merupakan mediator yang mempengaruhi hubungan antara likuiditas dan nilai perusahaan.

Interaksi Pertumbuhan Perusahaan (Asset Growth) dengan Struktur Modal (DER) memiliki nilai z ini lebih kecil dari 1,97 (1,5322 < 1,97) dengan tingkat probabilitas 0,0627, yang berarti Struktur Modal (DER) belum mampu menjadi mediator dalam hubungan antara Pertumbuhan Perusahaan (Asset Growth) dengan Nilai Perusahaan (PBV). Dalam penelitian ini, pertumbuhan perusahaan memberikan pengaruh positif pada struktur modal tetapi tidak berpengaruh signifikan. Tingginya tingkat pertumbuhan perusahaan menggambarkan perusahaan berada pada kondisi yang sehat sehingga memiliki kesempatan yang lebih besar dalam memperoleh pendanaan eksternal dan berdampak meningkatkan struktur modal perusahaan. Perusahaan yang mengalami pertumbuhan aset juga mengindikasikan perusahaan menggunakan pendanaan yang dimilikinya secara efektif dan efisien baik pendanaan internal maupun pendanaan eksternal. Hasil uji regresi tanpa interaksi struktur modal menunjukkan pertumbuhan aset memberi pengaruh positif pada nilai perusahaan namun tidak signifikan. Struktur modal belum dapat menjadi mediator yang mempengaruhi hubungan pertumbuhan perusahaan dan nilai perusahaan.

Kemudian, interaksi Ukuran Perusahaan (Firm Size) dengan Struktur Modal (DER) juga menghasilkan nilai z lebih kecil dari $1,97(1,3970<1,97)$ dengan tingkat probabilitas 0,0812, yang mengindikasikan bahwa Struktur Modal (DER) belum mampu menjadi mediator dalam hubungan antara Firm Size dengan PBV. Hasil uji regresi menunjukkan ukuran perusahaan memberikan pengaruh meningkatkan struktur modal perusahaan tetapi pengaruh tersebut tidak signifikan. Perusahaan besar seharusnya memiliki kemampuan yang lebih fleksibel untuk memperoleh pendanaan eksternal (Susanti dan Restiana, 2018).

Risiko yang rendah dimiliki oleh perusahaan besar karena dianggap dapat memiliki tingkat pengembalian investasi yang lebih tinggi kepada investor sehingga menambah rasa percaya investor pada perusahaan sehingga memberikan dampak positif pada nilai pasar dan nilai perusahaan. Kondisi ini juga seharusnya memudahkan perusahaan dalam mendapatkan pendanaan eksternal. Akan tetapi, hasil uji regresi dalam penelitian ini mengindikasikan semakin besar ukuran perusahaan akan memberikan pengaruh negatif serta signifikan pada nilai perusahaan. Dengan demikian, struktur modal belum dapat menjadi mediator yang mempengaruhi hubungan ukuran dan nilai dari perusahaan.

Hasil uji mediasi menyebutkan bahwa Struktur Modal (DER) mampu menjadi mediator atas hubungan profitabilitas dengan nilai dari perusahaan, namun belum dapat menjadi mediator antara likuiditas (CR), ukuran (Firm Size), dan pertumbuhan (Asset Growth), dengan nilai dari perusahaan (PBV). Hasil ini belum sejalan dengan (Salim dan Susilowati, 2019) yang menemukan Struktur Modal (DER) mampu menjadi mediator atas hubungan profitabilitas, likuiditas, ukuran, dan pertumbuhan dengan nilai dari perusahaan.

\section{KESIMPULAN}

Dalam penelitian ini, profitabilitas merupakan variabel yang berpengaruh menurunkan struktur modal secara signifikan, sementara variabel bebas lainnya tidak memberi pengaruh pada struktur modal. Secara kolektif, profitabilitas, likuiditas, pertumbuhan dan ukuran mempengaruhi struktur modal. Dalam hubungannya dengan nilai 
perusahaan, variabel yang mempengaruhi secara signifikan adalah profitabilitas, ukuran perusahaan, dan struktur modal. Struktur modal mendorong peningkatan, sementara profitabilitas dan ukuran pengaruhnya bersifat menurunkan nilai perusahaan. Kemudian, likuiditas dan pertumbuhan tidak memberi pengaruh terhadap nilai dari perusahaan. Uji mediasi yang dilakukan menunjukkan struktur modal menjadi mediator hanya untuk pengaruh profitabilitas terhadap nilai dari perusahaan.

Penelitian ini menggunakan sampel data tahun 2016-2018. Sampel data hanya dari perusahaan manufaktur. Sehingga, hasil penelitian belum dapat menjadi kesimpulan secara menyeluruh atas faktor-faktor apa saja yang berdampak menaikkan atau menurunkan tingkat struktur modal dan nilai dari perusahaan. Analisis untuk penelitian lanjutan dapat diperluas dengan menambah variabel bebas yang dapat memberikan pengaruh menaikkan atau menurunkan tingkat struktur modal dan nilai dari perusahaan. Analisis juga dapat diperdalam dengan menambah periode penelitian dan sampel industri non manufaktur sehingga dapat menghasilkan kesimpulan yang lebih menyeluruh.

\section{DAFTAR PUSTAKA}

Antoni, C. Chandra, dan F. Susanti. (2016) Faktor-Faktor Yang Mempengaruhi Struktur Modal Perusahaan Manufaktur Di Bursa Efek Indonesia. Jurnal Benefita 1(2) Juli 2016: 78-94 Kopertis Wilayah X 78.

Brigham, E. F. dan J. F. Houston. (2011) Dasar-dasar Manajemen Keuangan. Alih bahasa Ali Akbar Yulianto, Buku dua, Edisi Sebelas. Jakarta: Salemba Empat.

Darsono, N. F. (2017) Faktor-Faktor Yang Mempengaruhi Struktur Modal Di Perusahaan Indonesia (Pada Perusahaan Manufaktur Yang Terdaftar Di BEI Tahun 2011-2014) Diponegoro Journal Of Accounting Volume 6, Nomor 3, Tahun 2017, Halaman 1-9. DOI: http://ejournal-s1.undip.ac.id/index.php/accounting

Dewi, A. I. Y. M. D dan G. M. Sudiartha. (2017). Pengaruh Profitabilitas, Ukuran Perusahaan, Dan Pertumbuhan Aset Terhadap Struktur Modal Dan Nilai Perusahaan. E-Jurnal Manajemen Unud, Vol. 6, No. 4, 2017: 2222-2252.

Indasari, A. P. dan I. K. Yadnaya. (2018). Pengaruh Profitabilitas, Growth Opportunity, Likuiditas, Dan Struktur Modal Pada Nilai Perusahaan. E-Jurnal Akuntansi Universitas Udayana, Vol.22.1, Januari (2018): 714-746. ISSN: 2302-8556. DOI: https://doi.org/10.24843/EJA.2018.v22.i01.p27.

Jacob, J. dan F. A. Taslim. (2017) The Impacts of The Ratio of Liquidity, Activity And Profitability Towards Company Value With Dividend Policy As Intervening Variables. IOSR Journal of Business and Management (IOSR-JBM) Volume 19, Issue 10. Ver. IV. October, 2017: 01-07. DOI: 10.9790/487X-1910040107 www.iosrjournals.org.

Prastika, N. P. Y. dan M. R. Candradewi. (2019) Pengaruh Profitabilitas, Struktur Aktiva, Dan Likuiditas Terhadap Struktur Modal Perusahaan Subsektor Konstruksi Bangunan Di BEI. E-Jurnal Manajemen, Vol. 8, No. 7, 2019 :4444-4473. DOI: https://doi.org/10.24843/EJMUNUD.2019.v08.i07.p16

Purwanto and J. Agustin. (2017). Financial Performance towards Value of Firms in Basic and Chemicals Industry, European Research Studies Journal, Volume XX, Issue 2A, 2017. 
Purwohandoko. (2017) The Influence of Firm'sSize, Growth, and Profitability on Firm Value with Capital Structure as the Mediator: A Study on the Agricultural Firms Listed in the Indonesian Stock Exchange. International Journal of Economics and Finance, Vol. 9, No. 8; 2017: 103-110.

Rahmansyah, O. H. dan Djumahir. (2018) Pengaruh Profitabilitas, Struktur Modal, Ukuran Perusahaan, Likuiditas, Dan Peluang Pertumbuhan Terhadap Nilai Perusahaan (Studi Pada Perusahaan Makanan Dan Minuman Di Bursa Efek Indonesia). Jurnal Ilmiah Mahasiswa FEB Universitas Brawijaya, Vol. 16 No. 2, 2018.

Salim, M. N. dan R. Susilowati. (2019). The Effect of Internal Factors on Capital Structure and Its Impact on Firm Value: Empirical Evidence From The Food and Beverages Industry Listed on Indonesia Stock Exchange 2013-2017. International Journal of Engineering Technologies and Management Research, Vol. 6 (Iss. 7), July 2019: 173191. DOI: 10.5281/zenodo.3359550.

Susanti, N. dan N. G. Restiana. (2018). What's The Best Factor to Determining Firm Value? Jurnal Keuangan dan Perbankan, 22(2): 301-309.

Suwardika, I. N. A., dan I. K. Mustanda. (2017). Pengaruh Leverage, Ukuran Perusahaan, Pertumbuhan Perusahaan, Dan Profitabilitas Terhadap Nilai Perusahaan Pada Perusahaan Properti. E-Jurnal Manajemen Unud, Vol. 6 No. 3, 2017: 1248-1277. ISSN : 2302-8912.

Tasir, M., R. Andini, dan A. Pranaditya. (2017) The Effect Of Profitability, Asset Structure, Sales Growth, Liquidity, Firm Size To The Capital Structure ( Study Of Transportation Companies Are Listed On The Stock Exchange In The Period 20122015 ). JurnaL Ilmiah Mahasiswa S1 Akuntansi Universitas Pandanaran, Vol. 3, No. 3, Maret 2017.

Wahyu, D. D. dan M. K. Mahfud. (2018). Analisis Pengaruh Net Profit Margin, Return On Assets, Total Assets Turnover, Earning Per Share, Dan Debt To Equity Ratio Terhadap Nilai Perusahaan (Studi Pada : Perusahaan Manufaktur Yang Terdaftar Di Bursa Efek Indonesia Periode 2010-2016). Diponegoro Journal Of Management. Volume 7 Nomor 2 Tahun 2018. DOI: http://ejournals1.undip.ac.id/index.php/dbr.

Wardani, M. (2015) Analisis Pengaruh Profitabilitas, Likuiditas Dan Struktur Aktiva Terhadap Struktur Modal Pada Perusahaan Manufaktur Yang Terdaftar Di BEI Tahun 2011-2013. E-Thesis and Dissertations Universitas Muhammadiyah Surakarta, Agustus 2015.

Wirianata, H. (2020) Faktor-Faktor Yang Mempengaruhi Nilai Perusahaan Dengan Moderasi GCG, Jurnal Ekonomi Universitas Tarumanagara, Vol 24, No 3 (2019), November 2019: 468-487. DOI: http://dx.doi.org/10.24912/je.v24i3.610

Yastini, N. P. Y. A. dan I. M. Mertha. (2015) Pengaruh Faktor Fundamental Terhadap Nilai Perusahaan di Bursa Efek Indonesia.

Zuhroh, I. (2019) The Effects of Liquidity, Firm Size, and Profitability on the Firm Value with Mediating Leverage. The 2nd International Conference on Islamic Economics, Business, and Philanthropy (ICIEBP) Theme: "Sustainability and Socio Economic Growth”, KnE Social Sciences, pages 203-230. DOI: 10.18502/kss.v3i13.4206.

https://industri.kontan.co.id/news 